\title{
WHY THE WORLD SUDDENLY CARES ABOUT GLOBAL SUPPLY CHAINS
}

\author{
GARY GEREFFI AND JOONKOO LEE \\ Duke University
}

\begin{abstract}
The global value chain (GVC) concept has gained popularity as a way to analyze the international expansion and geographical fragmentation of contemporary supply chains and value creation and capture therein. It has been used broadly in academic publications that examine a wide range of global industries, and by many of the international organizations concerned with economic development. This note highlights some of the main features of GVC analysis and discusses the relationship between the core concepts of governance and upgrading. The key dynamics of contemporary global supply chains and their implications for global production and trade are illustrated by: (1) the consolidation of global value chains and the new geography of value creation and capture, with an emphasis on China; (2) the key roles of global supermarkets and private standards in agri-food supply chains; and (3) how the recent economic crisis contributes to shifting end markets and the regionalization of value chains. It concludes with a discussion of the future direction of GVC analysis and a potential collaboration with supply chain researchers.
\end{abstract}

Keywords: global value chain; supply chain management; international/global purchasing; outsourcing (make or buy); literature survey

\section{INTRODUCTION}

Global supply chains have been a familiar part of the international business landscape for decades. From a management perspective, there are always issues connected with the efficient and timely distribution of goods that flow across supply chains. From an industry perspective, there are questions about how the industry is organized in terms of the size and ownership of major manufacturers and their suppliers, and where these companies are located. From a national competitiveness perspective, countries are concerned about whether they can gain and maintain the production, sales and research capabilities needed to develop and make low-cost, high-quality or high-tech products (Pisano and Shih 2009). Finally, global supply chains matter for international development too, as the ability of countries to prosper depends on their participation in the global economy, which is largely a story about their role in global supply chains.

Despite its relevance on many levels, the literature on global supply chains tends to appear in a specialized set of publications oriented to a business audience. However, since the early 2000s, the global value chain (GVC) concept has gained popularity as a way to analyze the international expansion and geographical fragmentation of contemporary supply chains. The GVC analysis originated in a framework called global commodity chains, which emerged in the 1990s to link the concept of the value-added chain directly to the global organization of industries (Gereffi and Korzeniewicz 1994). As more research focuses on value creation and capture across the full range of possible chain activities, the GVC concept has become widely accepted as an overarching label for this body of literature (Gereffi et al. 2001; Gereffi 2005).

GVC studies are pervasive in academic publications that examine a wide range of global industries, ${ }^{1}$ and the framework has been adopted by many of the most important international organizations concerned with economic development, such as the World Bank (Cattaneo, Gereffi and Staritz 2010), the World Trade Organization (WTO and IDE-JETRO 2011), the Organization for Economic Cooperation and

\footnotetext{
${ }^{1}$ More than 635 publications were listed at the Global Value Chains website (http://www.globalvaluechains.org) as of April 10,2012 . For recent reviews of the GVC literature, see Bair (2009) and Lee (2010).
} 
Development (OECD 2011), the International Labor Organization (Gereffi 2006), the U.S. Agency for International Development (USAID 2011) and the U.S. International Trade Commission (USITC 2011).

In this research note, we highlight some of the main features of GVC analysis that contribute to its popularity, discuss the relationship between the core concepts of governance and upgrading and illustrate a few of the implications of a GVC approach to global production and trade.

\section{THE GOVERNANCE OF GLOBAL VALUE CHAINS}

Globalization has given rise to a new era of international competition that is reshaping global production and trade and thereby altering the organization of industries (Gereffi 2011). Since the mid-1960s, U.S. companies have been slicing up their supply chains in search of low-cost and capable suppliers offshore. This process of "global outsourcing" initially focused on the simple assembly of parts supplied by U.S. manufacturers, typified by the U.S. production-sharing or "twin plant" program with Mexico, but the pace of offshore production soon accelerated dramatically (Dicken 2011). In the 1970 s and 1980s, U.S. retailers and brand-name companies joined manufacturers in the search for offshore suppliers of most categories of consumer goods, which led to a fundamental shift from what had been "producer-driven" supply chains to "buyer-driven" chains. The geography of these chains expanded from regional production-sharing arrangements to full-fledged global supply chains, with a growing emphasis on East Asia (Gereffi 1996). In the 1990s and 2000s, the industries and activities encompassed by global supply chains grew exponentially, covering not only finished goods but also components and subassemblies, and affecting not just manufacturing industries, but also energy, food production and all kinds of services, from call centers and accounting, to medical procedures and core research and development (R\&D) activities of the world's leading multinational corporations (Engardio et al. 2003; Engardio and Einhorn 2005; Wadhwa et al. 2008).

As supply chains go global, more intermediate goods are traded across borders, and more parts and components are imported for use in exports (Feenstra 1998). In 2009, world exports of intermediate goods exceeded the combined export values of final and capital goods, representing 51 percent of nonfuel merchandise exports (WTO and IDE-JETRO 2011, p. 81). Governments and international organizations are taking notice of this emerging pattern of global trade, which is being called a shift from "trade in goods" to "trade in value added" and "trade in tasks" (OECD 2011; WTO and IDE-JETRO 2011).
The GVC framework focuses on globally expanding supply chains and how value is created and captured therein. By analyzing "the full range of activities that firms and workers perform to bring a specific product from its conception to its end use and beyond" (Gereffi and Fernandez-Stark 2011, p. 4), the GVC approach provides a holistic view of global industries from two contrasting vantage points: top down and bottom up. The key concept for the top-down view is the "governance" of global value chains, which focuses mainly on lead firms and the organization of global industries; the main concept for the bottom-up perspective is "upgrading," which focuses on the strategies used by countries, regions and other economic stakeholders to maintain or improve their positions in the global economy (Gereffi 2011).

Governance is the centerpiece of GVC analysis. It shows how corporate power can actively shape the distribution of profits and risk in an industry, and the actors who exercise such power through their activities. Within the chain, power is exerted by lead firms. In "producer-driven" chains, power is held by finalproduct manufacturers and is characteristic of capital-, technology- or skill-intensive industries. In "buyerdriven" chains, retailers or marketers of the final products exert the most power through their ability to shape mass consumption via strong brand names (Gereffi 1994).

The role played by lead firms is highlighted in various forms of GVC governance. Between the two extremes of markets and hierarchies (i.e., vertical integration), there are three network forms of governance: modular, relational and captive (Gereffi, Humphrey and Sturgeon 2005). In the network forms of GVC governance, the lead firm exercises varying degrees of power through the coordination of suppliers without any direct ownership of the firms (Figure 1).

- Market governance involves transactions that are relatively simple. Suppliers can make products with minimal input from and little coordination with buyers. Price is the central governance mechanism in the arm's-length relationship.

- Modular governance emerges when suppliers make products to a customer's specifications that are complex but relatively easy to codify. By exchanging information in the form of standards, buyers and suppliers reduce coordination costs.

- Relational governance exists when buyers and suppliers rely on complex information that is not easily transmitted. Frequent interactions and knowledge sharing based on mutual trust and social ties between parties are critical in coordinating relational chains.

- Captive governance is characterized by a group of small suppliers that are dependent on one or a 
FIGURE 1

Five Types of Global Value Chain Governance

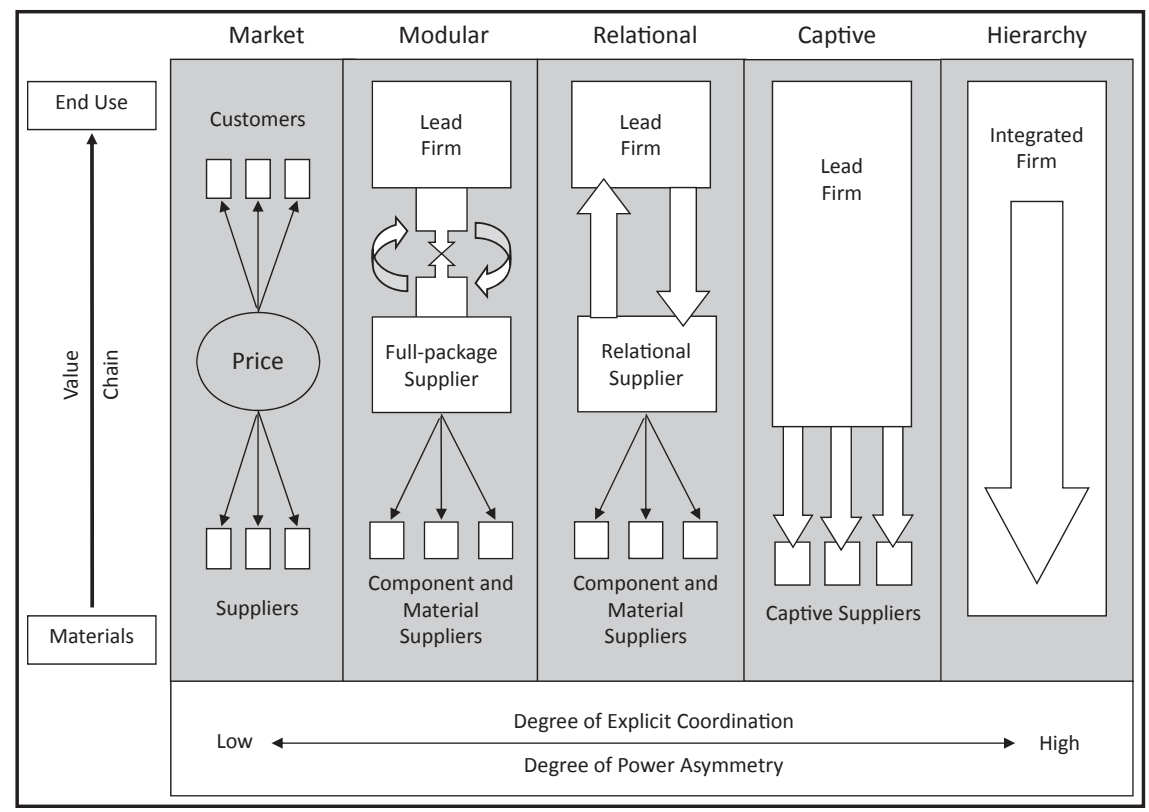

Source: Gereffi et al. (2005, p. 89).

few buyers in their resources and market access. Captive suppliers tend to operate under conditions set by, and often specific to, particular buyers.

- Hierarchical governance describes chains characterized by vertical integration and managerial control within lead firms that develop and manufacture products in-house.

The form of governance can change as an industry evolves and matures, and governance patterns within an industry can vary from one stage of the chain to another. Therefore, the descriptive typology outlined in Figure 1 is supported by a parsimonious explanatory model of the conditions under which various types of governance emerge and change over time (see Gereffi et al. 2005; Gereffi 2011).

\section{VIEWING THE GLOBAL ECONOMY THROUGH A GVC LENS}

To illustrate how GVC analysis reconceptualizes global production and trade, this section discusses three new and significant features of the global economy: the consolidation of global value chains and the new geography of value creation and capture, with an emphasis on China; the rise of global supermarkets and private standards in buyer-driven agrifood chains; and how the recent economic crisis contributes to shifting end markets and the regionalization of value chains.

\section{GVC Consolidation and the New Math of Value-Added Trade}

Over the past decade, many global value chains have experienced a shift in production from North to South in the global economy, and large emerging economies are playing very prominent roles in these industries as exporters and also new markets (Staritz, Gereffi and Cattaneo 2011). While most intermediate goods are still traded within large regional economic blocks like the European Union rather than across them (OECD 2011), Asia's linkages to the European Union and North America represented the two highest inter-regional import flows of intermediate goods in 2008. Asia imported more intermediate goods than it exported, indicating the region's high level of integration with global supply chains (WTO and IDE-JETRO 2011, pp. 83-85). The geographical concentration of supply chains is also obvious at the country and firm levels. In 2000-08, China accounted for 67 percent of the world's processing exports, followed by Mexico with 18 percent (WTO and IDE-JETRO 2011, p. 21). ${ }^{2}$ In electronics, manufacturing is concentrated to a handful of contract manufacturers (e.g., Hon Hai/Foxconn, Flextronics and Quanta), whose factories are also clustered in China (Sturgeon and Kawakami 2010).

China has benefited greatly from this high level of concentration in global supply chains. In China,

\footnotetext{
${ }^{2}$ Processing exports refer to exports that use duty-free imports for subsequent processing and re-export.
} 
one-third of its imports were destined to export-processing zones, which accounted for almost half of the country's exports (WTO and IDE-JETRO 2011, p. 21). China's "supply chain cities" are a perfect illustration of how China is turning scale-driven specialization into a persistent competitive advantage for the country. From foreign direct investment-driven clusters in Guangdong to single-product clusters in Zhejiang, China's sheer size has allowed it to develop broad manufacturing clusters at the regional level. These specialized clusters are linked, on the one hand, to East Asian suppliers of key parts and components, and on the other hand, to global buyers to bring Chinese products to the world market (Gereffi 2009).

Paradoxically, however, China does not create or capture most of the value generated through its value chain exports. In fact, as more types of intermediate goods are traded within global supply chains, the discrepancy is growing between where final goods are produced and exported and where value is created and captured. For example, Apple's iPhones are entirely assembled in China by a Taiwanese contract manufacturer (Foxconn) and exported to the United States. When a traditional measure is used that assigns the gross export value of the product to the exporting country, China is charged the total factory gate price (\$194.04) in its entirety for exporting one unit of the iPhone4, and it incurs a $\$ 169.41$ trade deficit with the United States for each unit shipped - i.e., the final good factory price (\$194.04) minus U.S. inputs sent to China (\$24.63) (see Figure 2).

In value-added terms, however, most of the value for the iPhone4 is created in Korea $(\$ 80.05)$, which supplies the two most expensive components - display panels and memory chips - for the product (Keller 2010), while China contributes only $\$ 6.54$ to the assembly of the iPhone4. Thus, the largest portion of the U.S. trade deficit from its iPhone4 imports is incurred not with China, but via indirect exports from Korea and other high-value component suppliers. This is not an exception for the world's largest manufacturing country. Domestic content only accounts for about half of China's manufacturing exports and it is even smaller (18 percent) in its processing exports, mostly done by foreign-owned firms (Koopman et al. 2008).

\section{Buyer-Driven Chains and the Rise of Private Standards}

One of the key insights that emerges from GVC analysis is the growing importance of global buyers as key drivers in the formation of internationally dispersed production and trade networks. Analysis of buyer-driven chains highlights the powerful role of large retailers, such as Walmart and Tesco, and highly successful brand-name merchandisers (e.g., Nike, Reebok), in dictating the way the chains are operated by requiring suppliers to meet certain standards (Gereffi 1994; Dolan and Humphrey 2004).

The role of global buyers has been strengthened by retail concentration. As shown in Figure 3, supply chains tend to be very concentrated in the retail segment (Humphrey and Memedovic 2006). Walmart, for example, has 8,100 stores across 15 countries with $\$ 401$ billion of annual revenue. With this enormous buying power, the world's largest retailer ranks as China's seventh largest trading partner (ahead of the

FIGURE 2

U.S. Bilateral Trade Balance with China for One Unit of the iPhone4 (US\$)

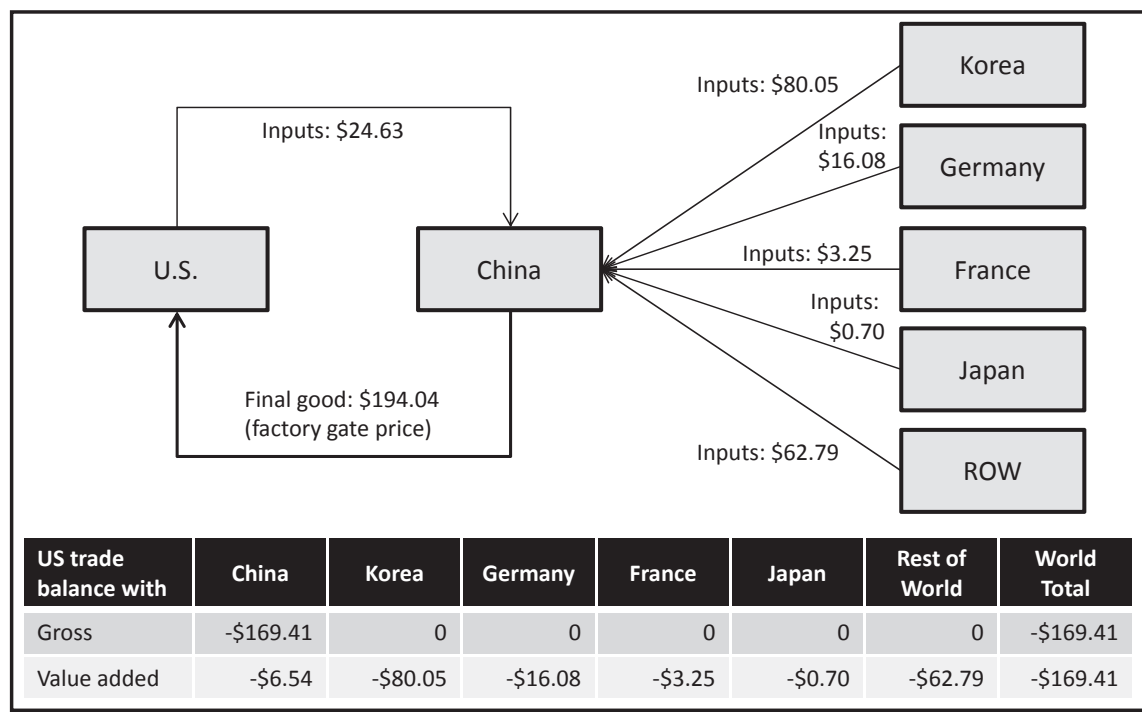

Source: OECD (2011, p. 40). 
FIGURE 3

The Supply Chain Funnel in the Agrifood Sector

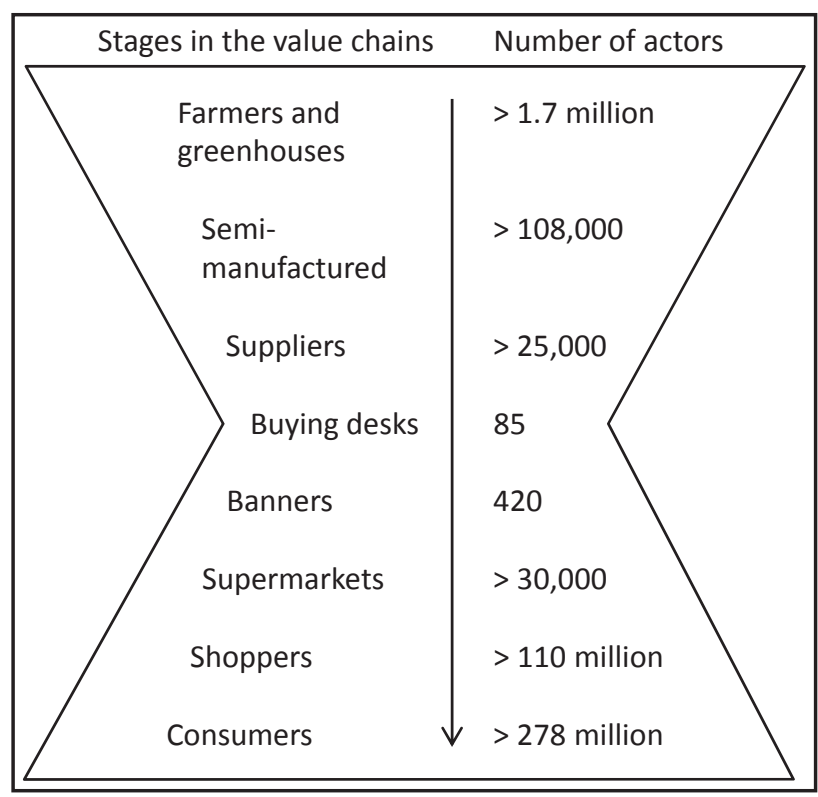

Source: Grievink (2008, p. 30)

Note: based on figures for seven Western European countries.

United Kingdom), spending more than $\$ 18$ billion annually on Chinese goods (Clark 2010). Also, large brand-name manufacturers wield significant buyer power in supply chains. Apple, for instance, has been successful in ensuring the availability of key components by placing large-volume orders and arranging prepayments to key suppliers (Satariano and Burrows 2011).

Quality standards are one of the key mechanisms by which buyers govern value chains. With growing product differentiation, ensuring quality becomes a critical element of market success. Growing consumer awareness of social and environmental concerns also leads retailers to tightly coordinate with their suppliers. A relatively new phenomenon of private quality standards set by powerful individual retailers aims to dictate which products are to be supplied, and how, when and where they will be produced (Lee et al. 2010).

Private standards have clear upgrading implications that go beyond business strategies. In agri-food chains, for example, to ensure food safety and quality from farm to fork, large food manufacturers and supermarkets work with a small group of preferred, generally large-scale suppliers capable of meeting their stringent and costly requirements. On the one hand, this standards-based consolidation marginalizes small farms unable to comply because of high costs and a lack of required skills (Dolan and Humphrey 2004; Maertens and Swinnen 2009). On the other hand, higher standards can be a catalyst for participation in high value- added chains, as proven by some smallholders who are successful in growing niche markets for organic or fair trade-certified products (Humphrey 2008).

\section{Shifting End Markets and Regional Supply Chains}

As world trade is bouncing back from the 2008-09 economic crises, developing economies are becoming the main engine of world economic recovery. Stagnant growth in demand in the global North since the mid-1980s was exacerbated by the latest crisis, whereas demand is quickly growing in the global South, particularly in large emerging economies like China, India and Brazil (Staritz et al. 2011). Over the period of 2005-10, the merchandise imports of the European Union and the United States increased by 27 percent and 14 percent, respectively, while emerging economies expanded their merchandise imports much faster: Brazil (147 percent), India (129 percent), China (111 percent) and South Africa (51 percent). In 2010, 52 percent of Asia's manufacture exports were destined for developing countries (WTO 2011), indicating shifting end markets in the global economy.

From a GVC perspective, this shift highlights the growing and distinctive roles of lead firms from developing countries vis-à-vis global buyers in reorganizing their supply chains. In Sub-Saharan Africa, for instance, the recent entry of South African clothing manufacturers into neighboring countries (such as Lesotho and Swaziland) has led to the rise of regional 
value chains driven by South African retailers. Compared to the U.S. retailer-driven chain, these regional chains focus on shorter production runs and quick response with higher fashion content, and are based on direct relationships to large South African clothing retailers (Morris, Staritz and Barnes 2011). Similarly, South African supermarkets are expanding via regional supply chains and leading the rise of supermarkets across Sub-Saharan Africa.

The GVC literature shows that value chains oriented to different end markets often entail distinct upgrading opportunities (Palpacuer, Gibbon and Thomsen 2005; Gibbon 2008). For example, the demand in lowerincome countries for less sophisticated products with regard to quality and variety can have major upgrading implications (Kaplinsky, Terheggen and Tijaja 2011). On the one hand, lower entry barriers and less stringent product and process standards in emerging markets can facilitate the participation of developing country firms in global supply chains. They can engage in higher value-added activities, such as product development and design, which they would have little chance to do in the global chains. With more intimate knowledge of local and regional markets vis-à-vis multinational firms, they can generate "frugal" innovations that are suitable to resource-poor environments (Clark et al. 2009). On the other hand, solely focusing on low-income markets could lock suppliers into slimmer margins and cutthroat competition. Their knowledge advantage in local markets often quickly evaporates when multinational firms catch up in learning the markets, as found in the Chinese mobile phone industry (Brandt and Thun 2011).

\section{BEYOND BUSINESS STRATEGIES}

The GVC paradigm links scholarly research on globalization with the concerns of both policy makers and social activists, who are trying to harness the potential gains of globalization to the pragmatic concerns of specific countries and social constituencies that feel increasingly marginalized in the international economic arena. Recently there is a growing concern in both developed and developing countries that the economic gains of participating in global supply chains do not necessarily translate into good jobs or stable employment, and in the worst case, economic upgrading may be linked to a significant deterioration of labor conditions, or social downgrading (Barrientos et al. 2011). ${ }^{3}$ Research is now being carried out to

\footnotetext{
${ }^{3}$ For example, the offshore production of high-tech electronics, such as Apple products, has led to the disappearance of middleincome jobs in the United States while generating a large group of Chinese workers suffering excessive working hours, violation of labor laws and hazardous factory conditions (see Duhigg and Barboza 2012; Duhigg and Bradsher 2012).
}

determine under what conditions participation in global value chains can contribute to both economic and social upgrading in developing countries (Lee et al. 2011).

A propitious development for policy-relevant research is the major advance in GVC metrics related to value creation and value capture (OECD 2011; WTO and IDE-JETRO 2011). As showcased by the iPhone study, existing trade statistics are not sensitive to changing patterns of global production and trade. This is also the area where GVC analysis and supply chain management research can be mutually beneficial. ${ }^{4}$ Sophisticated value chain data disaggregated by business functions can complement existing countrylevel trade statistics and industry-level input-output data, providing a clear picture of who is gaining and losing in global value chains (Sturgeon and Gereffi 2009). When combined with data on employment, they will greatly advance our understanding of both economic and social development opportunities in the global economy.

\section{RESEARCH IDEAS FROM THE GLOBAL VALUE CHAIN PERSPECTIVE}

There are several key GVC research issues that require a detailed understanding of global supply chains, and where JSCM readers and their Ph.D. students can make significant contributions. A core issue is mapping the "governance structures" of global supply chains. Figure 1 in this paper highlights five types of GVC governance structures (competitive markets; modular, relational and captive production networks; and vertically integrated firms or hierarchies). Recent research shows that most global industries are made up of a mix of these governance structures in different parts of the global supply chain, and these structures change over time and across different regions and country settings. This relationship classification will be broadly familiar to many supply chain scholars, and thus working at an industry level may be a natural extension of their current research.

The research required to map governance structures typically involves two steps: first, the input-output structure of the value chain needs to be identified in considerable detail (GVC case studies almost always contain diagrams of these input-output structures composed of boxes and arrows that map interconnected goods and services); and second, the research needs to overlay the main companies involved in different stages of the supply chain, and figure out where

\footnotetext{
${ }^{4}$ Note that the iPhone study and other similar studies (e.g., Linden, Kraemer and Dedrick 2009; Dedrick, Kraemer and Linden 2010) are based on tear-down analysis generated by supply chain management consultancy like iSuppli.
} 
the "lead firms" are located. This gives us the governance structure of an industry.

In the GVC framework, governance structures are interesting in and of themselves because they help identify opportunities and barriers to entry in the industry, which is of considerable importance to the competitive strategies of both lead firms and their various tiers of suppliers in these industries. Researchers need to learn how different industries (in the extractive, agricultural, manufacturing and service sectors) are organized, and the companies that make up these industries. Sourcing scholars, in particular, often have unparalleled access to a firm's decisions about supply base organization. Their knowledge would be most welcome in the widely read GVC outlets.

However, there are two related questions that also require detailed knowledge of global supply chains. First, both countries and companies are interested in knowing where value is created and captured at different stages or segments of a global value chain. The product-level GVC studies of iPods and iPhone 4 's show how surprising some of the results can be in trying to assess where and how much of the value added in these global supply chains accrues to specific countries (e.g., China versus the United States) and companies (Apple Inc. versus other manufacturing multinationals and lower-level suppliers). Supply chain scholars looking into multiple tiers of the supply base have the necessary knowledge to increase our understanding of the distribution of value throughout global supply chains.

Second, there is the question of the extent to which global supply chains are "inclusive" or "exclusive" in terms of facilitating the upgrading of lower-level firms in the chain. This kind of research requires us to develop precise indicators of "upgrading" (economic, social or environmental) relevant to supplier firms and the countries where they are located. A major research question is, "Under what conditions are lead firms in global value chains likely to facilitate upgrading by lower-tier suppliers?" Information about this would require interviews with firms across the supply chain to identify both mechanisms and outcomes that address this issue, and then the use of quantitative measures to allow the development of empirical indicators for each variable and appropriate generalizations from these findings.

\section{REFERENCES}

Bair, J. (Ed.), Frontiers of Commodity Chain Research, Stanford University Press, Stanford, CA, 2009.

Barrientos, S., G. Gereffi, and A. Rossi. "Economic and Social Upgrading in Global Production Networks: A New Paradigm for a Changing World," International Labour Review, (150:3-4), 2011, pp. 319-340.
Brandt, L., and E. Thun. "Going Mobile in China: Shifting Value Chains and Upgrading in the Mobile Telecom Sector," International Journal of Technological Learning, Innovation and Development, (4:1-3), 2011, pp. 148-180.

Cattaneo, O., G. Gereffi, and C. Staritz (Eds.), Global Value Chains in a Postcrisis World: A Development Perspective, World Bank, Washington, DC, 2010.

Clark, A. "Wal-Mart, the US Retailer Taking Over the World by Stealth," The Guardian, January 13, 2010, p. 26.

Clark, N., J. Chataway, R. Hanlin, D. Kale, R. Kaplinsky, L. Muraguri, T. Papaioannou, P. Robbins, and W. Wamae. "Below the Radar: What Does Innovation in the Asian Driver Economies Have to Offer Other Low Income Economies?," INNOGEN Working Paper, No. 69, Milton Keynes, UK, 2009 (http://oro.open.ac.uk/15241/).

Dedrick, J., K.L. Kraemer, and G. Linden. "Who Profits from Innovation in Global Value Chains?: A Study of the iPod and Notebook PCs," Industrial and Corporate Change, (19:1), 2010, pp. 81-116.

Dicken, P. Global Shift: Mapping the Changing Contours of the World Economy, 6th ed., Guilford Press, New York, 2011.

Dolan, C., and J. Humphrey. "Changing Governance Patterns in the Trade in Fresh Vegetables between Africa and the United Kingdom," Environment and Planning A, (36:3), 2004, pp. 491-509.

Duhigg, C., and D. Barboza. "In China, Human Costs Are Built into an iPad," The New York Times, January 26, 2012.

Duhigg, C., and K. Bradsher. "How the U.S. Lost Out on iPhone Work," The New York Times, January 22, 2012.

Engardio, P., and B. Einhorn. "Outsourcing Innovation," Business Week, March 21, 2005.

Engardio, P., A. Bernstein, and M. Kripalani. "Is Your Job Next?," Business Week, February 3, 2003.

Feenstra, R.C. "Integration of Trade and Disintegration of Production in the Global Economy," Journal of Economic Perspectives, (12:4), 1998, pp. 31-50.

Gereffi, G. "The Organization of Buyer-Driven Global Commodity Chains: How US Retailers Shape Overseas Production Networks." In G. Gereffi and M. Korzeniewicz (Eds.), Commodity Chains and Global Capitalism, Greenwood Press, Westport, CT, 1994, pp. 95-122.

Gereffi, G. "Commodity Chains and Regional Divisions of Labor in East Asia," Journal of Asian Business, (12:1), 1996, pp. 75-112.

Gereffi, G. "The Global Economy: Organization, Governance, and Development." In N. J. Smelser and R. Swedberg (Eds.), The Handbook of Economic Sociology, 2nd ed., Princeton University Press, Princeton, NJ, 2005, pp. 160-182.

Gereffi, G. The New Offshoring of Jobs and Global Development, ILO Social Policy Lectures, International Institute for Labour Studies and International Labor Organization, Geneva, 2006. 
Gereffi, G. "Development Models and Industrial Upgrading in China and Mexico," European Sociological Review, (25:1), 2009, pp. 37-51.

Gereffi, G. "Global Value Chains and International Competition," Antitrust Bulletin, (56:1), 2011, pp. 37-64.

Gereffi, G., and K. Fernandez-Stark. Global Value Chain Analysis: A Primer, Center on Globalization, Governance \& Competitiveness, Durham, NC, 2011 (http://www.cggc.duke.edu/pdfs/2011-0531_GVC_analysis_a_primer.pdf).

Gereffi, G., and M. Korzeniewicz (Eds.), Commodity Chains and Global Capitalism, Greenwood Press, Westport, CT, 1994.

Gereffi, G., J. Humphrey, R. Kaplinsky, and T.J. Sturgeon. "Introduction: Globalisation, Value Chains and Development," IDS Bulletin, (32:3), 2001, pp. 1-8.

Gereffi, G., J. Humphrey, and T. Sturgeon. "The Governance of Global Value Chains," Review of International Political Economy, (12:1), 2005, pp. 78-104.

Gibbon, P. "Governance, Entry Barriers, Upgrading: A Re-Interpretation of Some GVC Concepts from the Experience of African Clothing Exports," Competition and Change, (12:1), 2008, pp. 2948.

Grievink, J.-W. "New Business Services and Industry/ Retail Relations," presented at European Commission Conference "Competitiveness of the European Agro-food industry: Focus on Innovation and Agro-food Logistics," The Hague, Netherlands, Nov 27, 2008 (http://ec.europa.eu/enterprise/sectors/food/files/events/netherlands-2008/ pres_27_nov/jan-willem_grievink_en.pdf).

Humphrey, J. "Private Standards, Small Farmers and Donor Policy: EUREPGAP in Kenya," Institute of Development Studies Working Paper, No. 308, Sussex, Brighton, UK, 2008 (http://www.ids.ac.uk/ files/Wp308.pdf).

Humphrey, J., and O. Memedovic. "Global Value Chains in the Agrifood Sector," United Nations Industrial Development Organization Working Paper, Vienna, 2006 (http://www.unido.org/fileadmin/user_media/Publications/Pub_free/ Global_value_chains_in_the_agrifood_sector.pdf).

Kaplinsky, R., A. Terheggen, and J. Tijaja. "China as a Final Market: The Gabon Timber and Thai Cassava Value Chains," World Development, (39:7), 2011, pp. 1177-1190.

Keller, K. "iPhone 4 Carries Bill of Materials of \$187.51, According to iSuppli," iSuppli Press Release, $2010 \quad$ (http://www.isuppli.com/Teardowns/News/Pages/iPhone-4-Carries-Bill-of-Materials-of-187-51-According-to-iSuppli.aspx).

Koopman, R., Z. Wang, and S.-J. Wei. "How Much of Chinese Exports Is Really Made in China? Assessing Domestic Value-Added When Processing Trade Is Pervasive," National Bureau of Economic Research Working Paper, No. 14109, Cambridge, MA, 2008 (http://www.nber.org/papers/w14109).
Lee, J. "Global Commodity Chains and Global Value Chains." In R. A. Denemark (Ed.). The International Studies Encyclopedia, Wiley-Blackwell, Oxford, 2010, pp. 2987-3006.

Lee, J., G. Gereffi, and J. Beauvais. "Global Value Chains and Agrifood Standards: Challenges and Possibilities for Smallholders in Developing Countries," Proceedings of the National Academy of Sciences of the United States of America, 2010, doi: 10.1073/pnas.0913714108 (http://www.pnas.org/ content/early/2010/12/08/0913714108).

Lee, J., G. Gereffi, and S. Barrientos. "Global Value Chains, Upgrading and Poverty Reduction," Capturing the Gains Briefing Note, No. 3, 2011 (http://www.capturingthegains.org/pdf/ctg_briefing_note_3.pdf).

Linden, G., K.L. Kraemer, and J. Dedrick. "Who Captures Value in a Global Innovation Network?: The Case of Apple's iPod," Communications of the ACM, (52:3), 2009, pp. 140-144.

Maertens, M., and J.F.M. Swinnen. "Trade, Standards, and Poverty: Evidence from Senegal," World Development, (37:1), 2009, pp. 161-178.

Morris, M., C. Staritz, and J. Barnes. "Value Chain Dynamics, Local Embeddedness, and Upgrading in the Chothing Sectors of Lesotho and Swaziland," International Journal of Technological Learning, Innovation and Development, (4:1-3), 2011, pp. 96-119.

OECD. "Global Value Chains: Preliminary Evidence and Policy Issues," Organisation for Economic Co-operation and Development, DSTI/IND(2011) 3, Paris, 2011 (http://www.oecd.org/dataoecd/18/ 43/47945400.pdf).

Palpacuer, F., P. Gibbon, and L. Thomsen. "New Challenges for Developing Country Suppliers in Global Clothing Chains: A Comparative European Perspective," World Development, (33:3), 2005, pp. 409-430.

Pisano, G.P., and W.C. Shih. "Restoring American Competitiveness," Harvard Business Review, (87:7/ 8), 2009, pp. 114-125.

Satariano, A., and P. Burrows. "Apple's Supply-Chain Secret? Hoard Lasers," Bloomberg Businessweek, November 3, 2011.

Staritz, C., G. Gereffi, and O. Cattaneo. "Editorial," International Journal of Technological Learning, Innovation and Development, (4:1-3), 2011, pp. $1-12$.

Sturgeon, T.J., and G. Gereffi. "Measuring Success in the Global Economy: International Trade, Industrial Upgrading, and Business Function Outsourcing in Global Value Chains," Transnational Corporations, (18:2), 2009, pp. 1-36.

Sturgeon, T.J., and M. Kawakami. "Global Value Chains in the Electronics Industry: Was the Crisis a Window of Opportunity for Developing Countries?," World Bank Policy Research Working Paper, No. 5417. World Bank: Washington, DC, 2010.

USAID. "Value chain development," MicroLINKS wiki, 2011 (http://apps.develebridge.net/amap/index. php/Value_Chain_Development). 
USITC. The Economic Effects of Significant U.S. Import Restraints: Seventh Update 2011. Special Topic: Global Supply Chains. Publication 4253, United States International Trade Commission, Washington, DC, 2011.

Wadhwa, V., U.K. De Vitton, and G. Gereffi. "How the Disciple Became the Guru: Workforce Development in India's R\&D Labs," Report prepared for the Ewing Marion Kauffman Foundation, 2008 (http://papers.ssrn.com/sol3/papers.cfm? abstract_id $=1170049)$.

WTO. International Trade Statistics 2011, World Trade Organization, Geneva, 2011.

WTO and IDE-JETRO. "Trade Patterns and Global Value Chains in East Asia: From Trade in Goods to Trade in Tasks," World Trade Organization and Institute of Developing Economies, Geneva and Tokyo, 2011 (http://www.ide.go.jp/English/Press/ pdf/20110606_news.pdf).

Gary Gereffi (Ph.D., Yale Univeristy) is a professor in the Department of Sociology at Duke University in Durham, North Carolina. He also serves as the Director of the University's Center on Globalization, Governance \& Competitiveness. Dr. Gereffi's research interests focus on globalization, industrial upgrading and social and economic development around the world. He has written articles and reports that were published by research centers and international nongovernmental organizations, including the International Institute of Labor Studies and the World Bank. His articles also have appeared in peer-reviewed academic journals, such as World Development and the Journal of International Economics.

Joonkoo Lee (Ph.D., Duke University) is a postdoctoral research scholar at the Social Science Research Institute at Duke University in Durham, North Carolina. His research interests include globalization and development, economic sociology, global value chains, global cultural industries and comparative political economy in Asia. Dr. Lee's dissertation compared the historical development of the animation industry in South Korea and India, from a global value chain perspective. His published articles have appeared in the Proceedings of the National Academy of Sciences (USA), the Journal of Hunger and Environmental Nutrition, Media Asia, and The International Studies Encyclopedia. 